Historic, Archive Document

Do not assume content reflects current scientific knowledge, policies, or practices. 



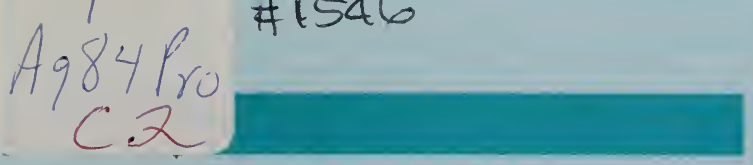

\section{Wetlands and} Agriculture:

Section 404 of the
Clean Water Act

Swampbuster in the Food Security Act

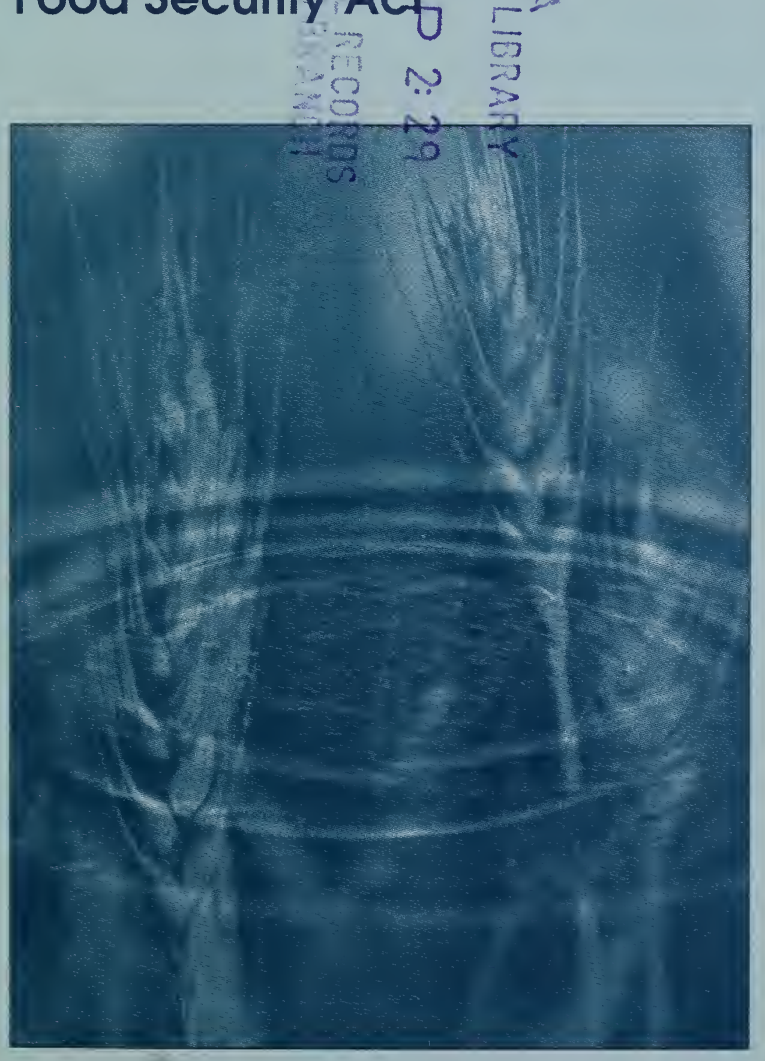

\section{Contact the Natural Resources Conservation Service to Identify Wetlands on Your Farm}

Program Aid 1546

\section{What are wetlands?}

Wetlands are areas that are inundated or saturated by surface or ground water at a frequency and duration sufficient to support, and that under normal circumstances do support, a prevalence of vegetation typically adapted for life in saturated soil conditions. For further guidance on whether your land contains wetlands, contact your local Natural Resources Conservation Service (NRCS) office, formerly the Soil Conservation Service.

\section{What is the Swampbuster provision?}

The Wetland Conservation provision (Swampbuster) of the 1985 and 1990 farm bills requires all agricultural producers to protect the wetlands on the farms they own or operate if they want to be eligible for USDA farm program benefits. Producers will not be eligible if they plant an agricultural commodity on a converted wetland that was converted by drainage, leveling, or any other means after December 23, 1985, or convert a wetland for the purpose of or to make agricultural commodity production possible after November 28, 1990.

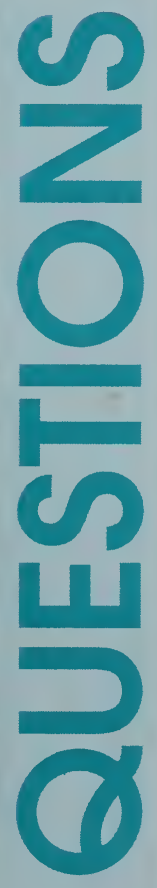

\section{What does Section 404 require?}

Section 404 of the Clean Water Act (CWA) requires a landowner to obtain a permit from the U.S. Army Corps of Engineers (Corps) prior to beginning any non-exempt activity involving the placement of dredged or fill material in waters of the United States, including wetlands. Certain ongoing, normal farming practices in wetlands are exempt and do not require a permit (see list of exempted activities). In order to be exempt, the activities cannot be associated with bringing a wetland into agricultural production or converting an agricultural wetland to a non-wetland area.

\section{How does the Swampbuster pro-} gram relate to CWA Section 404? Generally, areas subject to regulation under Swampbuster and CWA Section 404 are the same, but there are differences. Some activities that are exempted under Swampbuster may require a CWA Section 404 permit while some Section 404 permitted activities may be subject to Swampbuster. Before beginning any activity affecting a wetland, contact your local Corps district or NRCS office. 


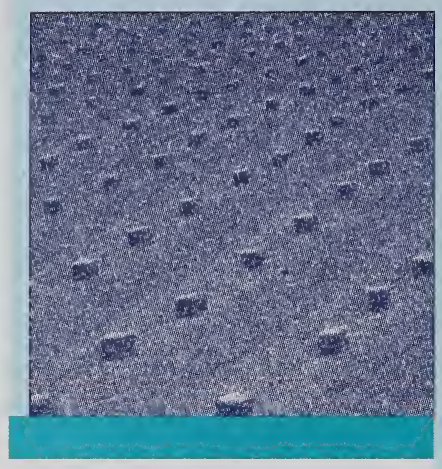

Farming Activities That Are Exempt From Section 404

Contact the Corps before undertaking these activities in wetlands and other waters of the United States to verify applicability of the exemptions.

- Established (i.e., ongoing), normal farming activities

- plowing

- harvesting

- seeding

- minor drainage

- cultivating

- Maintenance, but not construction, of drainage ditches

- Construction and maintenance of irrigation ditches

- Construction and maintenance of farm or stock ponds

- Construction and maintenance of farm roads, in accordance with best management practices

\section{Questions to Answer Before Starting a New Activ}

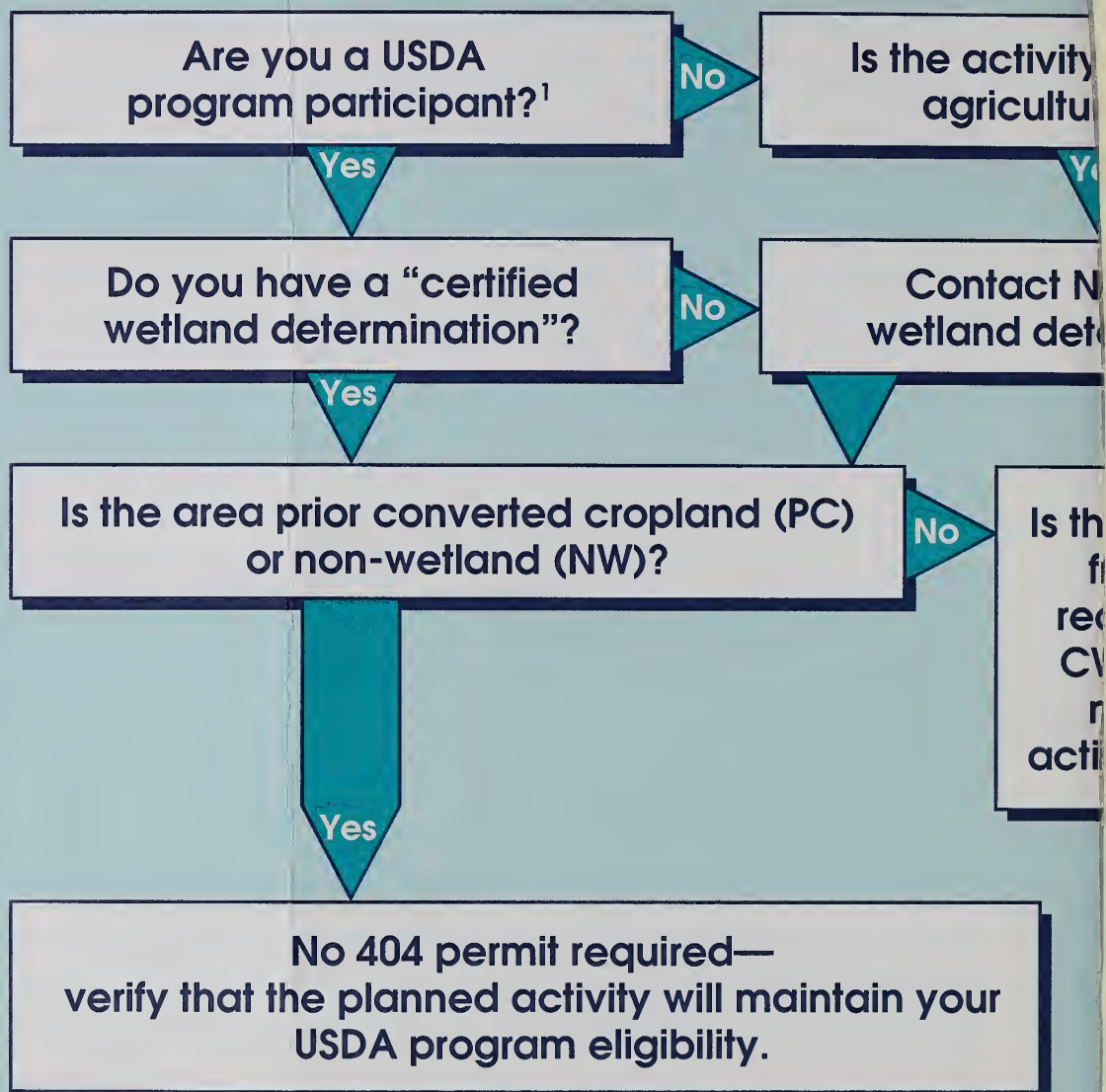

${ }^{1}$ USDA program participants are required to document their intent to manipulate wet area

\section{Types Of Section 404 Permits Issued By The Corp}

Individual permits are issued to a single entity (individuals or companies) to authorize specific activities. Once a complete permit application is received by the Corps, a public notice is issued which describes the proposed project. The Corps evaluates all comments received and makes a final permit decision.

For phone numbers of your NRCS state offi NCRS state offices have phone nu 


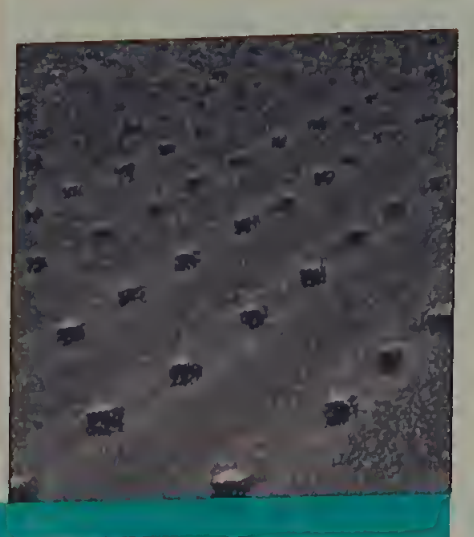

Farming Activities That Are Exempt From Section 404

Contact the Corps before undertaking these activities in wetlands and other waters of the United waters of the United ty of the exemptions.

- Establlshed (i.e., ongoing), norma farming activities - plowing - harvesting - seeding - minor drainage - cultivating

- Maintenance, but not construction, of drainage ditches

- Construction and maintenance of irrigation ditches

- Construction and maintenance of farm or stock ponds

- Construction and maintenance of farm roads. in accordance with best management practices
Questions to Answer Before Starting a New Activity

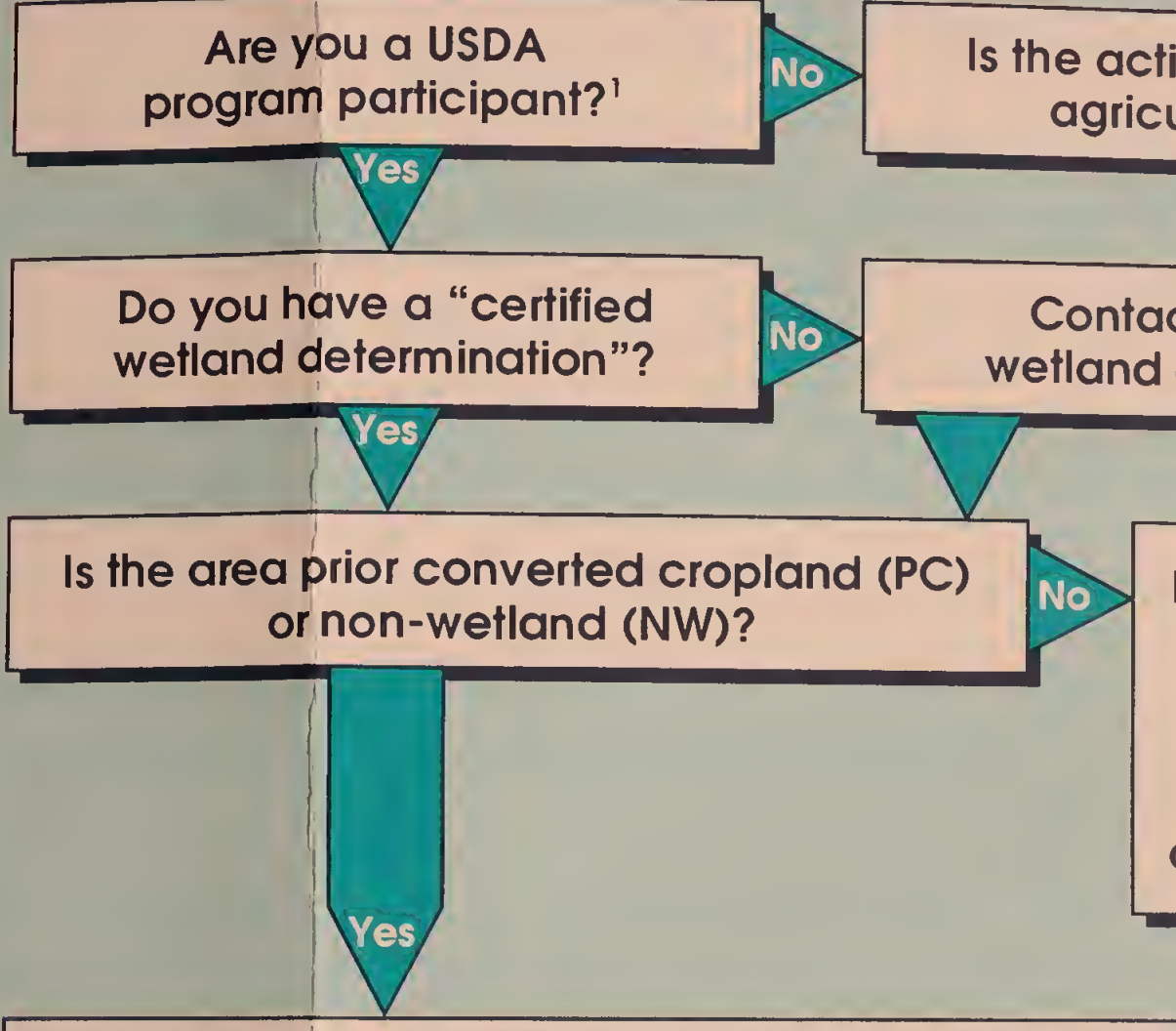

No 404 permit required-

verify that the planned activity will maintain your USDA program eligibility.
Is the activity exempt from the permit requirement under CWA 404(f)? Most

normal farming activities are exempt.
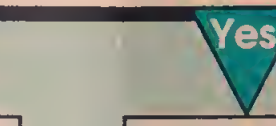

No 404 permit required - verify with the Corps Consult with NRCS to assure compliance with Swampbuster.
Agricultural lands are lands intensively used and managed for the production of food or fiber to the extent that the natural vegetation has been removed and cannot be used to determine whether the area meets applicable hydrophytic vegetation criteria in making a wetland delineation. Areas that meet this definition may include intensively used and managed cropland. hayland, pasture land, orchards, vineyards, and areas which support wetland crops (e.g., cranberries, taro. watercress, rice). Agricultural lands do not include range lands, forest lands, wood lots, or tree farms.
${ }^{1}$ USDA program participants are required to document their intent to manipulate wet areas on Form AD-1026 at the local USDA Consolidated Farm Service Agency office.

\section{Types Of Section 404 Permits Issued By The Corps}

Individual permits are issued to a single entity (individuals or companies) to authorize specific activities. Once a complete permit application is received by the Corps, a public notice is issued which describes the proposed project. The Corps evaluates all comments received and makes a final permit decision.

General permits are issued to the public-at-large to authorize specific activities that have minimal environmental impacts such as bank stabilization activities or construction of farm buildings. A general permit can be issued on a State, regional, or nationwide basis. Activities quthorized by a general permit require less review than an individual permit would require.

For phone numbers of your NRCS state office and Corps district, call 1-800-832-7828. NCRS state offices have phone numbers for local NRCS field offices.

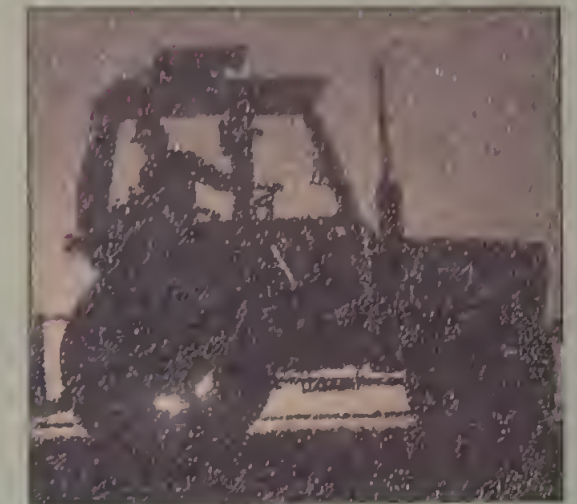




\section{What is prior converted cropland?}

Prior converted croplands (PC) are wetlands that were drained, dredged, filled, leveled, or otherwise manipulated, including the removal of woody vegetation, before December 23 , 1985 , to make production of an agricultural commodity possible, and that (1) do not meet specific hydrologic criteria, (2) have had an agricultural commodity planted or produced at least once prior to December 23, 1985, and (3) have not since been abandoned. Activities in prior converted cropland are not regulated under Swampbuster or CWA Section 404.

\section{What happens if I don't farm my prior converted cropland and wetland conditions return?}

If prior converted cropland is not planted to an agricultural commodity for more than 5 consecutive years and wetland characteristics return, the cropland is considered abandoned and then becomes a wetland subject to regulation under Swampbuster and CWA Section 404.

\section{What are farmed wetlands?}

Farmed wetlands (FW) are similar to prior converted cropland in that they were drained, dredged, filled, leveled, or otherwise manipulated before December 23, 1985, to make production of an agricultural commodity possible, but are often wet enough to still be valuable wetland habitat subject to Swampbuster and CWA Section 404. Farmed wetlands include potholes, playas, pocosins, and other manipulated and cropped areas that meet specific hydrologic criteria.

\section{How do I know if I have wetlands, prior converted croplands, or farmed wetlands on my property?}

To be sure about the status of wetlands on your farm, contact your local NRCS office. NRCS is the lead Federal agency responsible for wetland delineations on agricultural land for both Swampbuster and CWA Section 404. NRCS conservationists can also advise you on how to comply with Swampbuster. The Corps is the lead Federal agency responsible for wetland delineations on non-agricultural land for anyone who does not participate in USDA programs. For questions regarding CWA Section 404 provisions, contact your local Corps office.
This brochure was prepared jointly by

USDA Natural Resources Conservation Service

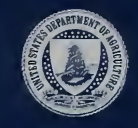

U.S. Army Corps of Engineers

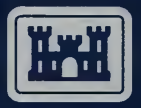

U.S. Environmental Protection Agency

\section{BEPA}

U.S. Fish and Wildlife Service

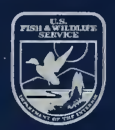

For additional information on wetlands, call EPA's

Wetlands Information Hotline 1-800-832-7828

Monday-Friday, 9:00 am to 5:30 pm (EST)

The Hotline is contractor operated and provides confidential referrals and information regarding wetlands.

\section{May 1995}

The United States Department of Agriculture (USDA) prohibits discrimination in its programs on the basis of race, color, national origin, sex, religion, age, disability, political beliefs and marital or familial status. (Not all prohibited bases apply to all programs.) Persons with disabilities who require alternative means for communication of program information (Braille, large print, audiotape, etc.) should contact the USDA Office of Communications at (202) 720-5881 (voice) or (202) 720-7808 (TDD).

To file a complaint, write the Secretary of Agriculture, U.S. Department of Agriculture, Washington, DC, 20250, or call (202) 720-7327 (voice) or (202) 720-1127 (TDD). USDA is an equal employment opportunity employer. 